\title{
THE EFFECT OF DIFFERENT SUBSTRATE ON THE MORPHOLOGICAL CHARACTERISTICS OF HUNGARIAN TAGETES PATULA CULTIVARS
}

\author{
Máté ÖRDÖGH ${ }^{1 *}$ \\ ${ }^{* 1}$ Department of Floriculture and Dendrology, Urban Planning and Garden Art, Institute of \\ Landscape Architecture, Hungarian University of Agriculture and Life Sciences, Budapest, \\ Magyarország
}

\author{
*Correspondence: \\ ordogh.mate@uni-mate.hu
}

Received: 31 May 2021; Accepted: 11 June 2021; Published: 30 June 2021

\begin{abstract}
The aim of this trial was to find the optimal substrate (sand, peat and 1:1 mixture of them) for germination and growing of Tagetes patula 'Robuszta Kénsárga', 'Vénusz' and 'Tigris', with the use of 40 seeds according to substrates and cultivars in nine groups. Germination and survival ratio, plant height, root length, flower number and -diameter were examined. Almost all seeds germinated successfully, and the highest surviving was around $80 \%$ in case of peat + sand, and the lowest $(50 \%)$ when plants grown in pure sand. The latter substrate resulted the longest roots (especially in the groups of 'Tigris') and all cultivars (particularly 'Vénusz') reached the lowest height with the use of this soil. On the other hand, peat effected the shortest roots, tallest specimens, most flowers of every cultivars. In case of flower number, there were significant differences between 'Tigris' (with averagely 58-70 flowers) and the other two types (23-39 flowers), irrespectively of the substrates. 'Vénusz' developed the smallest flower heads (maximum $3.5 \mathrm{~cm}$ ) in all cases; the other cultivars produced at least $4 \mathrm{~cm}$ inflorescences. The lowest plant values experienced with the use of sand and the best results on peat.
\end{abstract}

Keywords: Tagetes patula, substrates, germination, plant height, rooting, flowering.

\section{Introduction}

Tagetes patula cultivars are one of the most popular annual ornamental bedding or balcony plants with typical flatted or halfglobular flower head, a special inflorescence including ,petal" shaped ray and smaller, circle formed disc flowers, which structures is typical of nearly all members of the Asteraceae family (Udvardy, 2008). These Tagetes varieties usually grow as compact, small plants with short stems and low $(15-45 \mathrm{~cm})$ height (Howe and Walters, 1990). Several flower colours (yellow, orange, red, two-coloured, marbled etc.) and types (simple, half- or full) are available, thanks to the crossbreeding of certain species as $T$. patula, T. erecta, T. tenuifolia, $T$. filifolia and T. lucida. Most of them are densely branched, shrub-liked herbaceous plants (originated from northern part of South America and south-western regions of the USA) with pinnately lobed, deeply serrated, aromatic; glandulous leaves (Schmidt, 2002; Adams, 2004). Certain taxa (especially $T$. erecta) are applicable as medicinal plant, essential oil of the flowers contains antioxidants (Gutiérrez et al., 2006), and presence of flavonoids, tannins, saponins, carotenoids in Tagetes species have been reported (Riaz et al., 2013). Extracts of herbs 
has been applied against respiratory problems (cold, bronchitis) and decoction of florets, leaves used as treatment of muscular, bone and abdominal pains, skin, kidney and eye diseases. Curative products of these annuals has diuretic, carminative effects (Maity et al., 2011; Dixit el al., 2013; Kadam et al., 2013; Manisha et al., 2013) or beneficial to reduce high levels of cholesterol and hypertension (Raghuveer et al., 2011). Additionally, examinations on different taxa of Tagetes genus proved their insecticidal effects; which reduced populations of certain insects such as mosquitos (Marcia et al. 2011; Nikkon et al., 2011), moreover, nematodes (Kiranmai et al., 2011). Hungarian cultivars (bred by Zoltán Kováts) usually produce bright, durable flowers in large quantities during whole summer and September-October (until the first frosty days) and tolerates unfavourable especially drought conditions. In this particular case (as sowing trial), some of these cultivars were used, such as the yellow flowered, medium sized (around $40 \mathrm{~cm}$ tall) 'Robuszta Kénsárga', the orange coloured, smaller (25-30 $\mathrm{cm})$ 'Vénusz' and 'Tigris', an exceed, upright (70-80 $\mathrm{cm})$ type with yellow and red striped flowers, as shown in Fig. 1. (Tillyné and Honfi, 2011; Szabó, 2020).

Several substrates can be used for plant propagation and growing. One of the cheapest is sand, but (especially comparing with peat) certain disadvantages (e.g. heavier weight, less porous structure) often give us difficulties during sowing, cutting and plant care. Mixtures of sand + peat (with 1:3 to 3:1 ratio) had better physical and chemical parameter, which usually stimulate effectively plants' development, mainly rooting (Schmidt and Tóth, 1996). Properly selected substrates are one of the main factors affecting growth of plants, and optimal media have large water capacity, high porosity and durable, stabile structure (Fascella, 2015). In horticultural production, peat or peat-coconut based substrates are highly used (especially for the cultivation of bedding and balcony plants), however, these substrates can be substituted by cheaper soils (Dobrowolska and Janicka, 2014).

\section{Materials and methods}

Three In the first decade of May 2019, seeds (120 pieces per cultivar, originated from Fruit Culture Research and Development Institute, Budapest and Érd, Hungary) were sown into plug trays (with $4 \times 4 \mathrm{~cm}$ cells) filled with fluvial sand (collected from the river Tisza), peat (marked as TS2, KlasmannDeilmann, Germany) and 50-50\% mixture of these substrates.

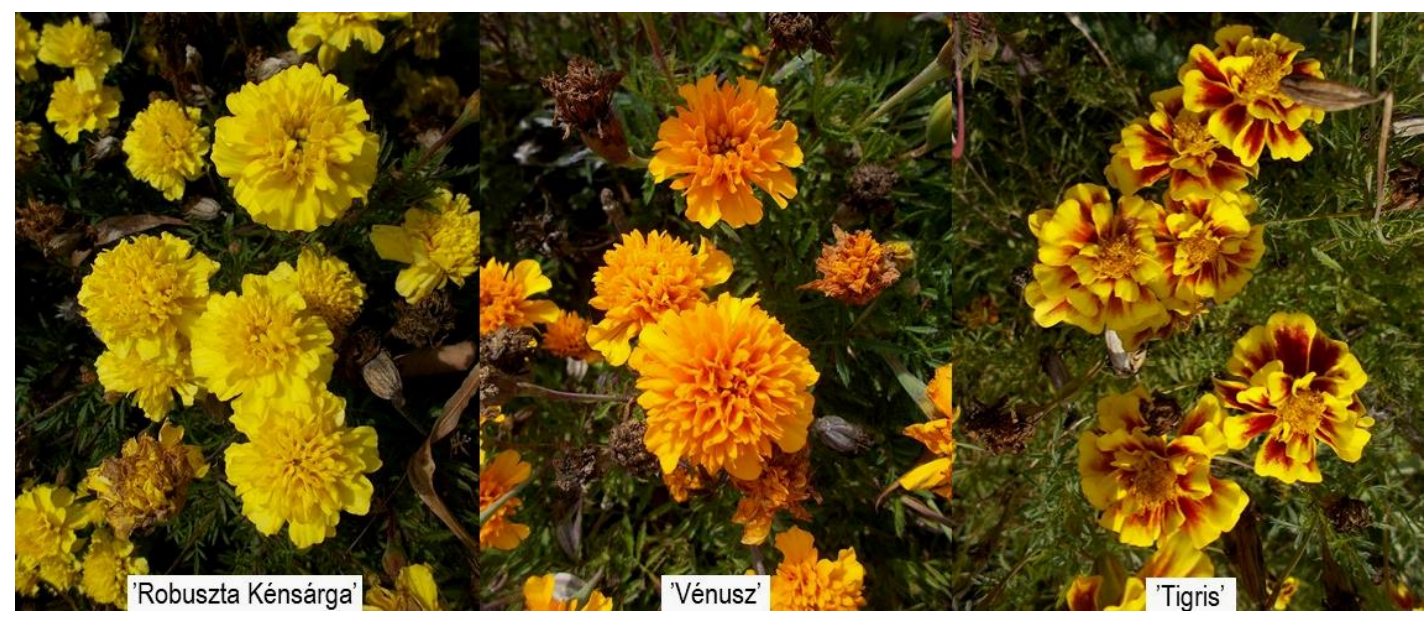

Fig. 1. Hungarian Tagetes patula cultivars with different flower colours 
Each groups contain 40 seeds according to the three Hungarian cultivar and substrates:

1. group: 40 'Vénusz' seeds sown into sand

2. group: 40 'Robuszta Kénsárga' seeds sown into sand

3. group: 40 'Tigris' seeds sown into sand

4. group: 40 'Vénusz' seeds sown into 50$50 \%$ sand+peat

5. group: 40 'Robuszta Kénsárga' seeds sown into $50-50 \%$ sand+peat

6. group: 40 'Tigris' seeds sown into 50$50 \%$ sand+peat

7. group: 40 'Vénusz' seeds sown into peat

8. group: 40 'Robuszta Kénsárga' seeds sown into peat

9. group: 40 'Tigris' seeds sown into peat
At the end of May, all germinated specimens were replanted into plastic pots measuring $10 \mathrm{~cm}$ over (with the same substrates). Until planting out to open field, young plants were grown in unheated, unlit polytunnel without chemical pest control and fertilization. From germination to the end of life, different parameters such as germinate and survival ratio, plant height, root length, flower number and flower diameter were measured (Fig. 2).

Data were evaluated by Ropstat statistical software (Vargha, 2002, 2008). An analysis of variance (ANOVA) was conducted to calculate the statistical significance of all data presented. In cases of significant differences, means were separated by Tukey's test at $p<0.1, p<0.05$.

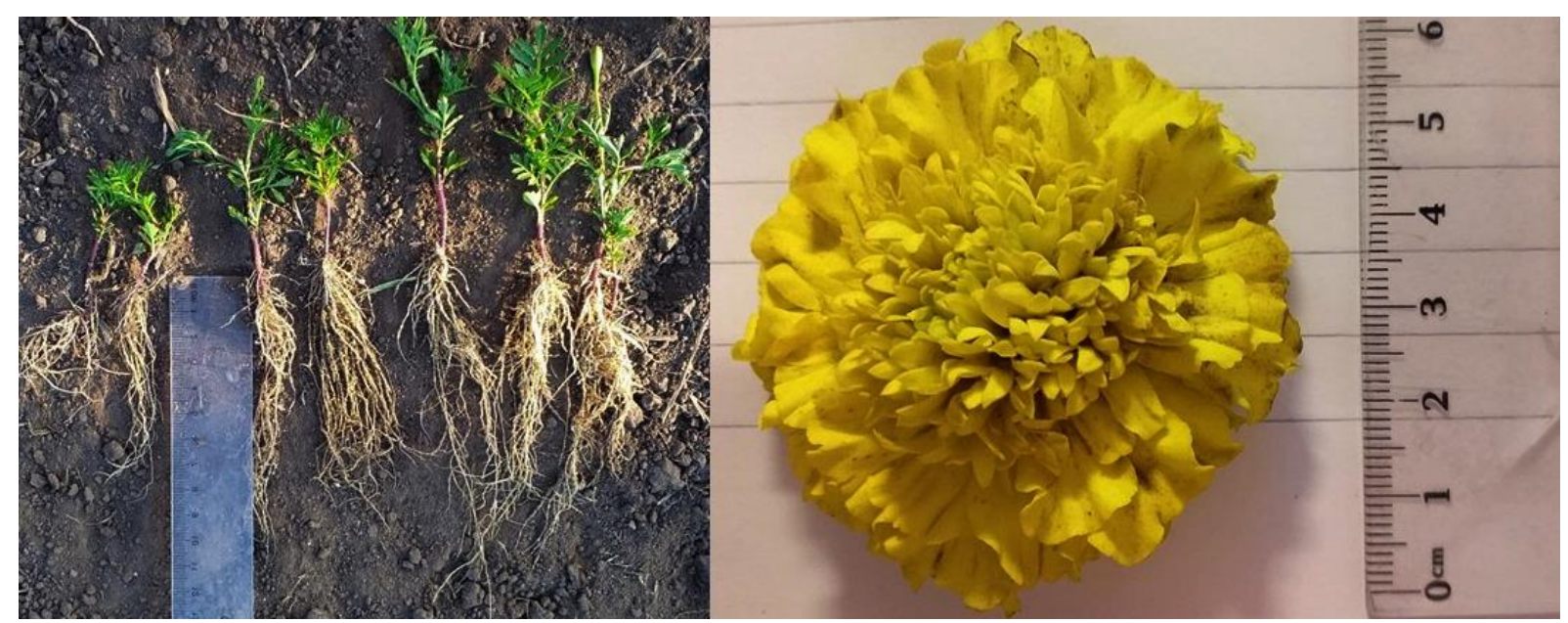

Fig. 2. Examination of root length and flower diameter

\section{Results and discussion}

\subsection{Germination rate}

Four days after sowing on $12^{\text {th }}$ May, first seedlings ('Robuszta Kénsárga') were found on sand + peat and further four days following, all of them sprouted but only on pure peat (Fig. 3). In case of the other cultivars and substrates, 1-3 seed did not germinated, so, most of them successfully start their life, irrespective of the soils/cultivar (excepting 'Vénusz' seeds in sand: only 35 of them germinated well). In another study, Tagetes erecta seeds germinated similarly fast, within 5-8 days (Kadam et al., 2012), but other taxa, for example $T$. caracasana required longer period (3 weeks) and reached only 61-69\% germination both in greenhouse and laboratory (Herrera-Moreno et al., 2013). T. minuta sprouted completely in 1015 days with variable values (from 50 to $83 \%$ ) depending on the culture environments, usually special, controllable sowning conditions (Petri dishes, filter papers) resulted higher percentages than in case of use pots and solid substrates such as sand (Ferreira et al., 2001; Singh et al., 2003). 


\subsection{Number of survived plants}

Until 30th November (when first frost days destroy all plants), the highest plant number reduction (16-16 specimens) was obtained in case of 'Robuszta Kénsárga' and 'Tigris' groups on $100 \%$ peat or also pure sand. The latter soil resulted similarly strong decrease of 'Vénusz' plant number; overall, this substrate negatively affected all Tagetes patula cultivars' survival, because of the bad water storage (after planting out, all groups were grown without irrigation, so as to ascertain, which is the best drought tolerant cultivar). At the same time, combination of $50 \%$ peat and $50 \%$ sand enhanced survival ratio: only 7-9 individuals died before flower production, considering all cultivars (Fig. 4).

\subsection{Plant height}

Plants reached lower height on pure sand (in case of every groups) and $100 \%$ peat eventuated the largest growth (Fig. 5).

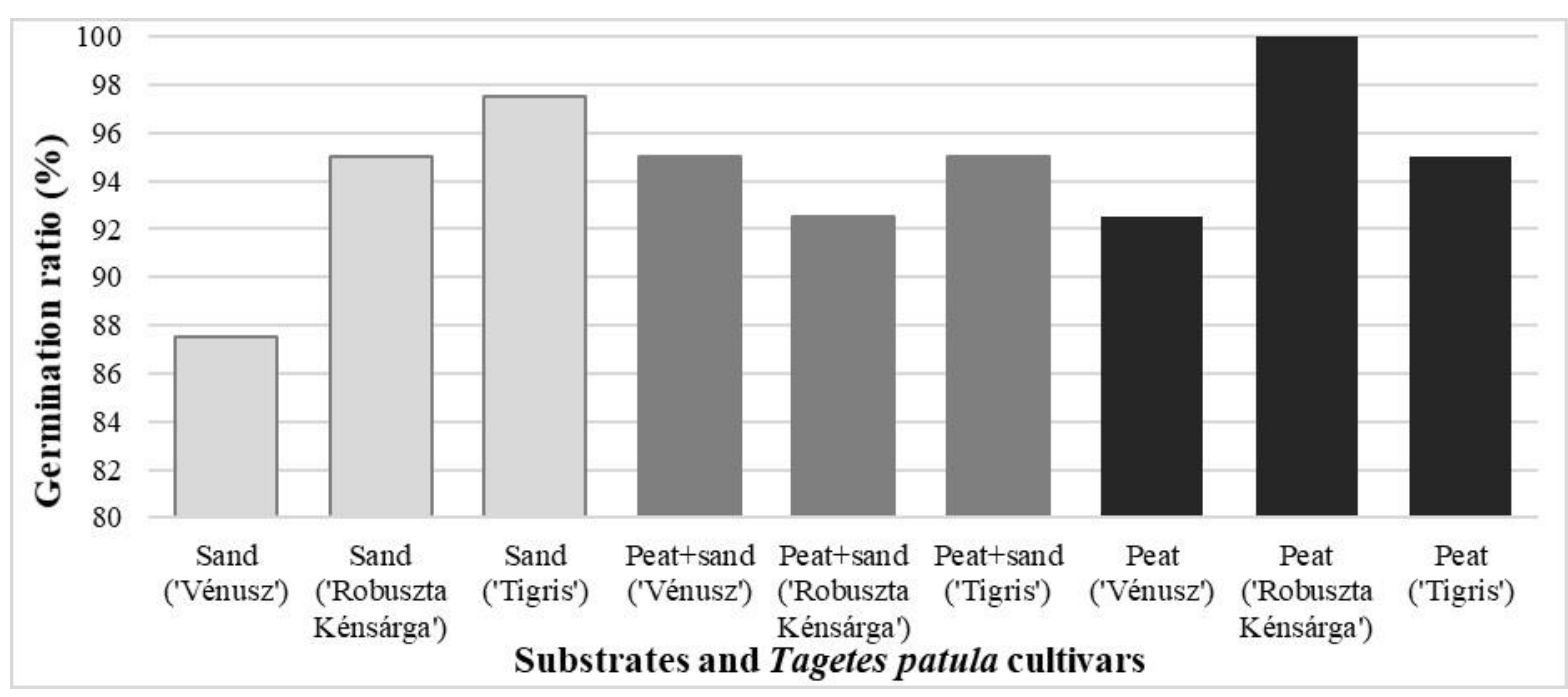

Fig. 3. Germination of Tagetes patula cultivars on different substrates ( 8 days after sowing)

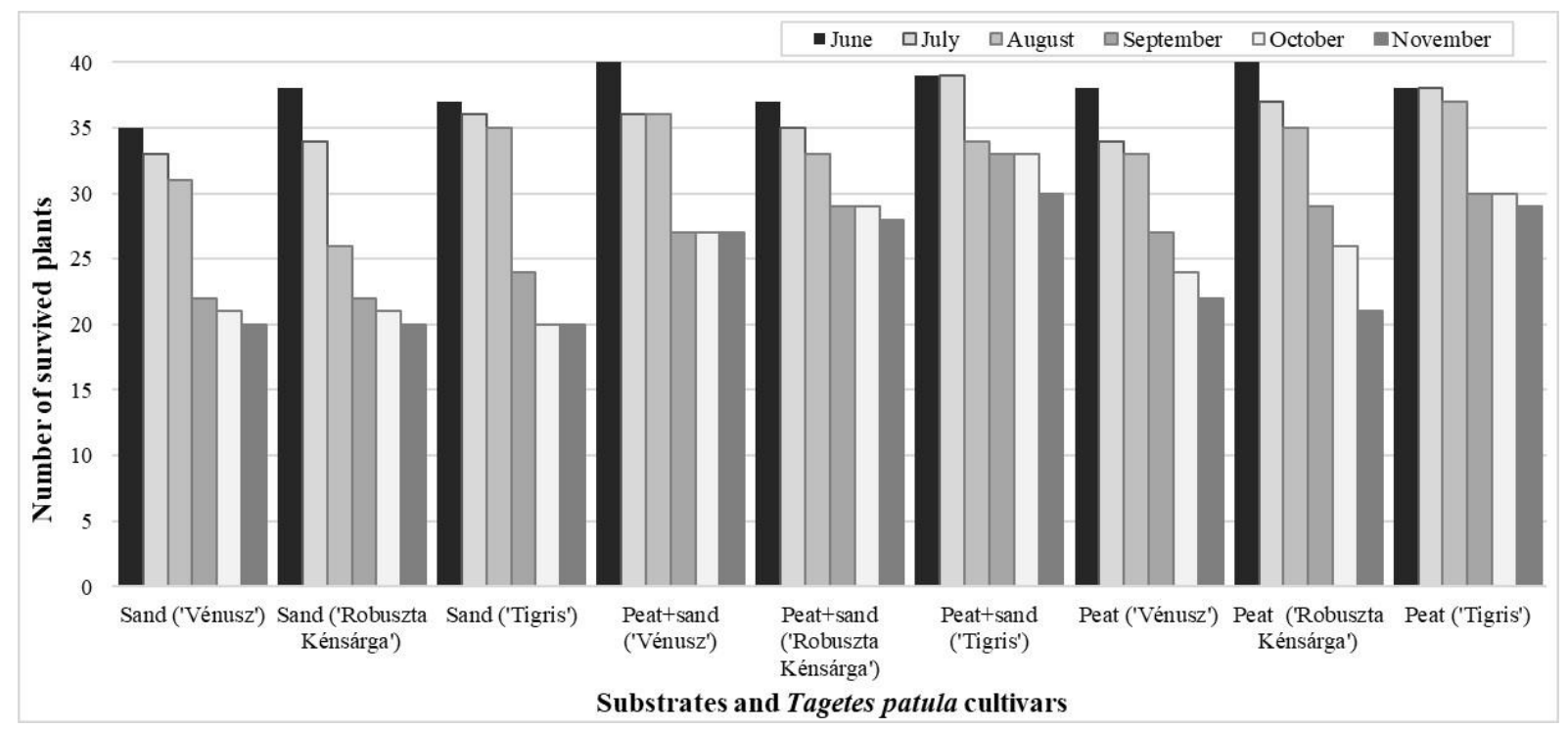

Fig. 4. Number of survived plants of Tagetes patula cultivars on different substrates

(June-November 2019) 
In another study of investigating the effect of various substrates (for example compost, flower soil, peat-coconut, peat TS1) on the development of $T$. erecta 'Marvel Mixture', 'Taishan Orange' and T. patula 'Durango Red' and 'Bonanza Flame', results showed that all specimens grown in peat TS1 had longer, thicker stems and larger height (Maślanka and Magdziarz, 2017).

On the other hand, cultivars (as an important factor) influenced average plant height (the highest was 'Tiger' with almost 60 cm size and the lowest was 'Vénusz', which grown not more than $22 \mathrm{~cm}$ on peat and $18 \mathrm{~cm}$ on sand. 'Robuszta Kénsárga' reached middle values (peat: almost $35 \mathrm{~cm}$, sand: not more than $23 \mathrm{~cm}$ ). Significant differences detected mainly between the cultivars, even on the same substrates. Considerable variances were also observed between 'Super Giant' and 'Inca F1' $T$. erecta cultivars when plants cultured in the same medium (1:1:1 mixture of sand, silt and leaf compost); the latter variety became taller and produced longer shoots (Riaz et al, 2013).
Comparing water-stressed (non-irrigated) stocks of $T$. erecta, $T$. patula and $T$. tenuifolia, Romanian and Hungarian, cultivars on 2:1:1 peat, vermiculite and perlite, great differences were recorded among not only species but also cultivars. Especially Hungarians ( $T$. patula 'Orion' and 'Színkeverék', T. erecta 'Alacsony Citromsárga' and 'Aranysárga', T. tenuifolia 'Sárga') developed much shorter shoots with lower height in dry conditions (Cicevan et al., 2016).

\subsection{Estimated spread of root system}

In order to determine a rough degree of rooting (without serious root damages during repotting and examination of fragile plants' roots), estimated values (percentages) were ascertained according to the spread of root system inside the substrate. Thus, plants has the smallest results $(20-45 \%)$ on sand and the largest values (50-85\%) on peat. Comparing the cultivars, 'Vénusz' produced the least and 'Tigris' developed the greatest root system, irrespective of the substrate type (Fig. 6).

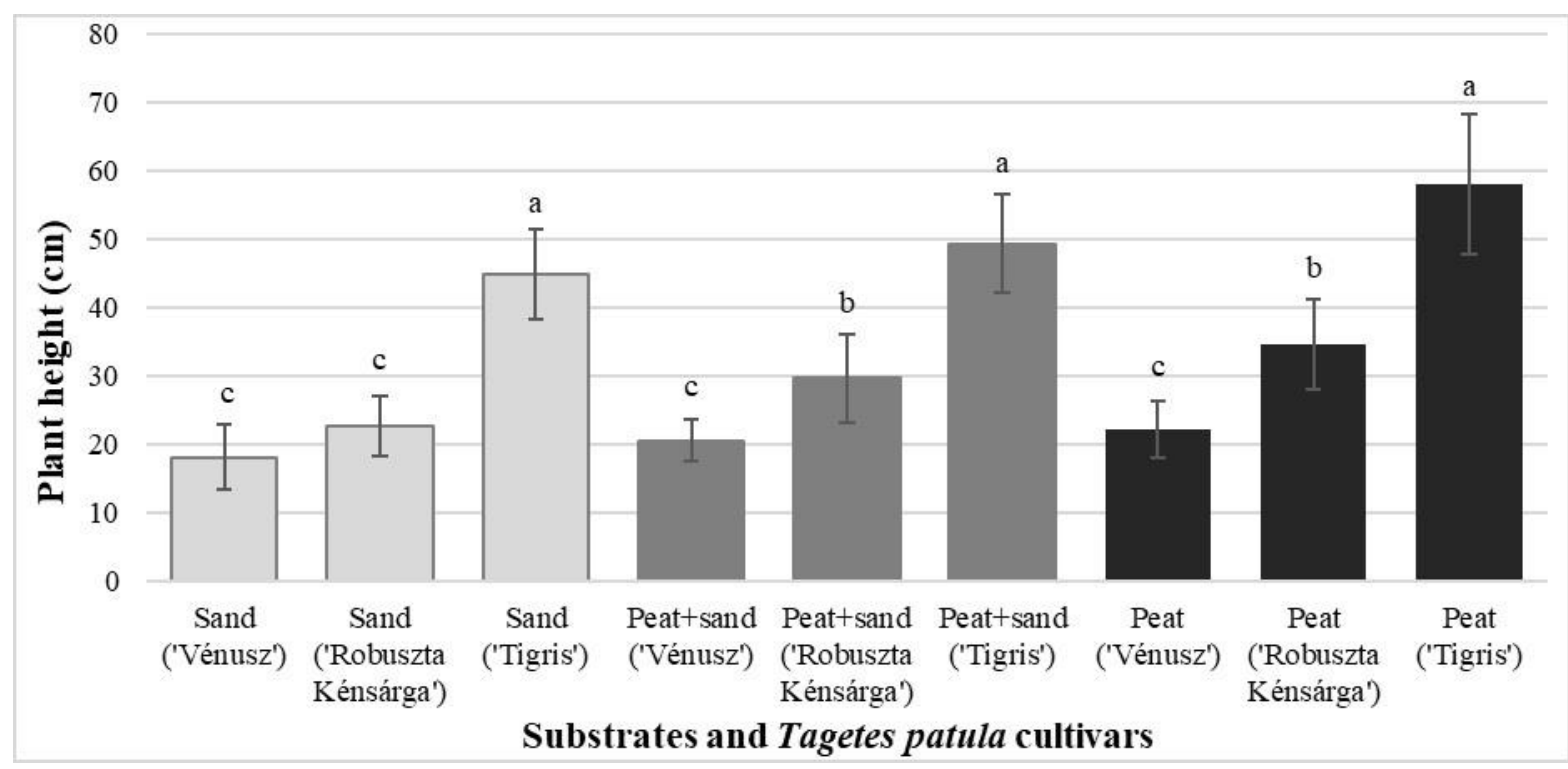

Fig. 5. Plant height of Tagetes patula cultivars on different substrates (November 2019) 


\subsection{Length of roots}

Significantly, the longest roots were found on plants which germinated and grown on pure sand, and $100 \%$ peat resulted the shortest ones. Also considerable differences were observed between the cultivars; 'Tigris' plants developed the longest (longer than $20 \mathrm{~cm}$ ) and 'Vénusz' produced the shortest $(15.27 \mathrm{~cm})$ roots with the use of sand (Fig. 7). Additionally, we noticed inverse proportion between the length and estimated spread, therefore, poorly rooted plants (with smaller root system) usually created longer roots (chiefly in $100 \%$ sand) and plants with strong, well-developed root ball has shorter ones (mainly with the use of pure peat).

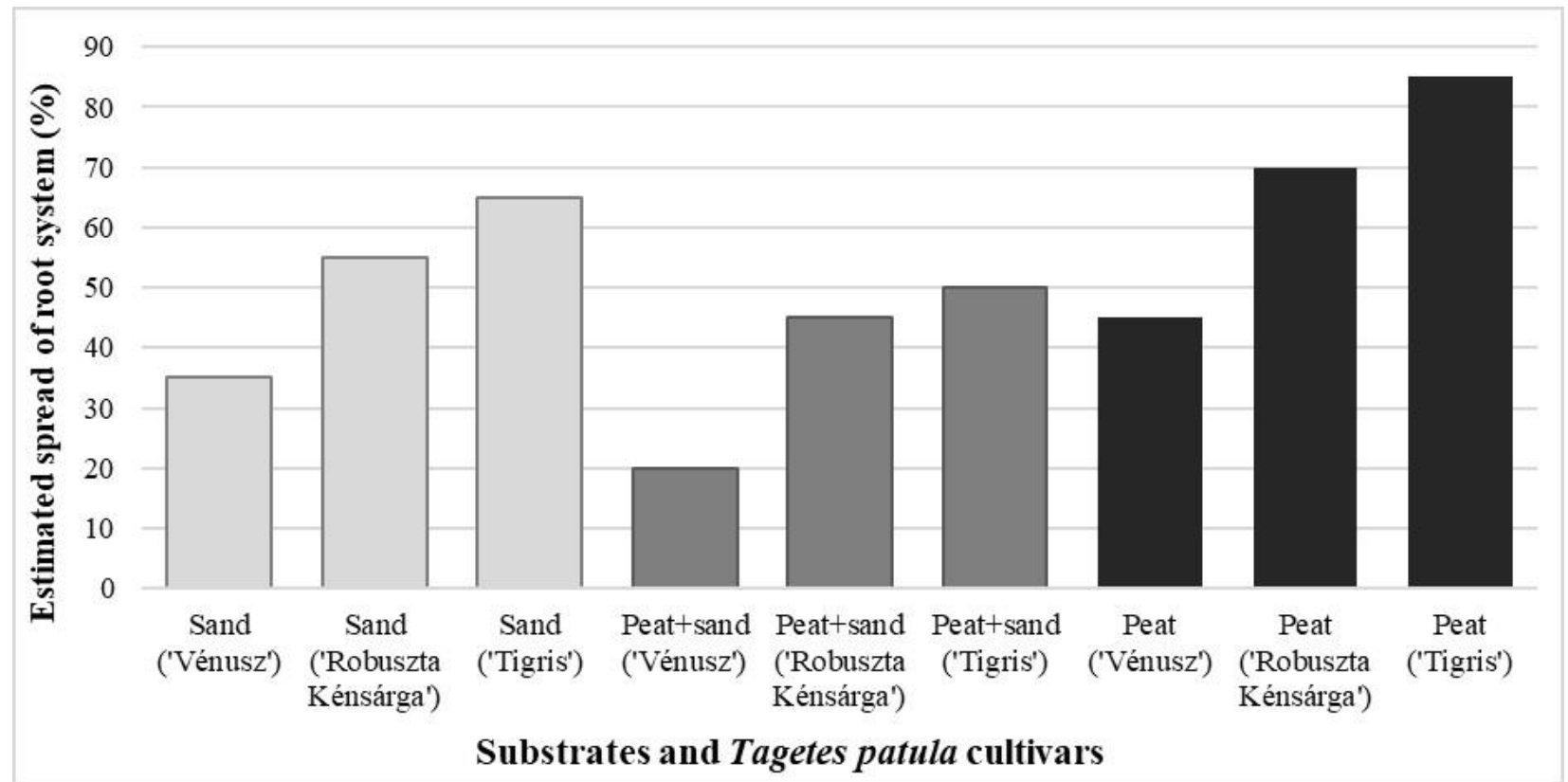

Fig. 6. Estimated spread of root system of Tagetes patula cultivars on different substrates (May 2019)

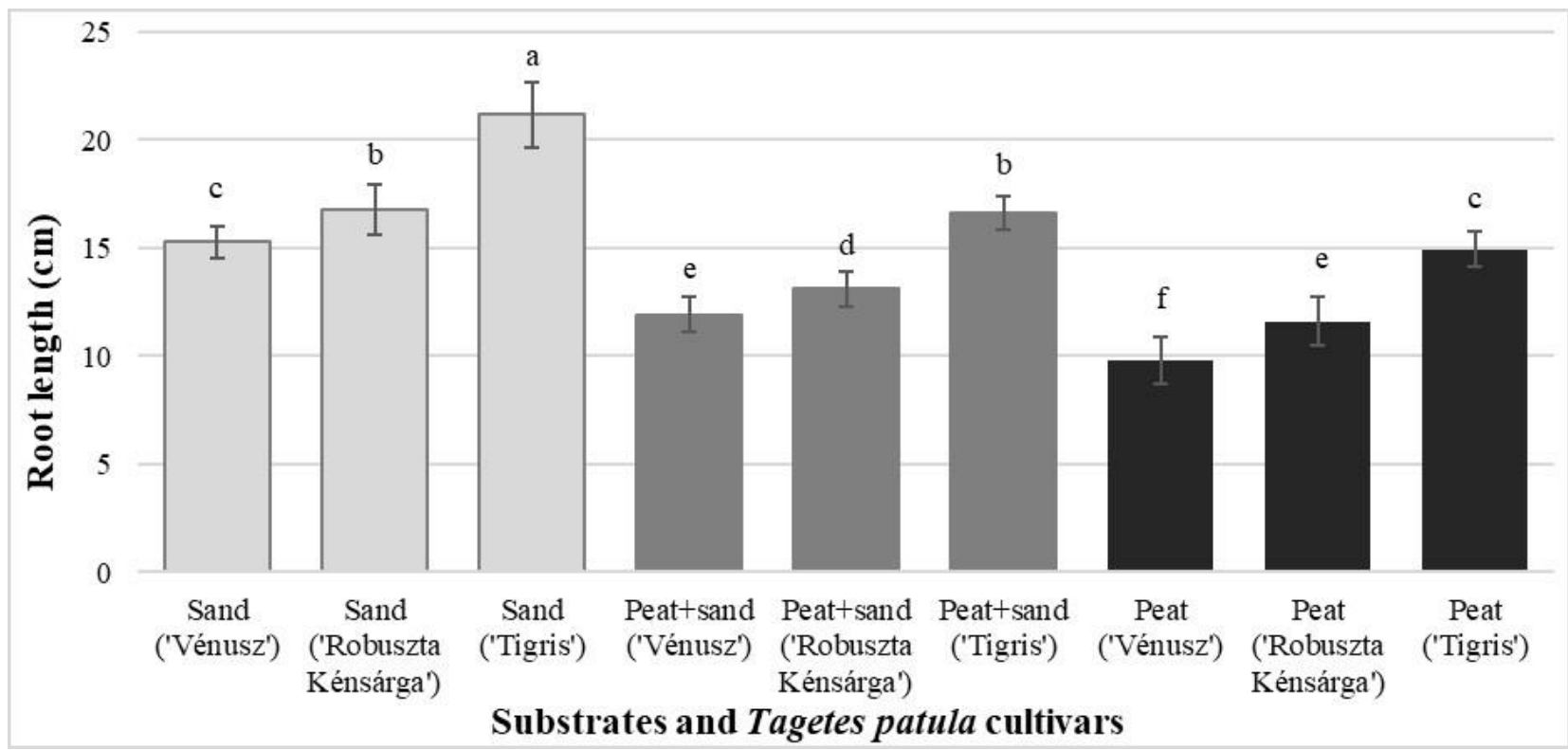

Fig. 7. Root lenght of Tagetes patula cultivars on different substrates (May 2019) 


\subsection{Number of flowers}

The first full-blown flower was found at the beginning of July in the 'Robuszta Kénsárga' stock grown on peat, and 'Tiger' and 'Venus' groups which also cultivated on the same substrate opened second. Sand-grown 'Robuszta Kénsárga' and 'Vénusz' plants produced their first flower at the latest. In the case of average time from the sowing to the first flowers, 'Robuszta Kénsárga' had the shortest period (61 days) and 'Vénusz' required the longest time (65 day). It is worth notify that the latter cultivar developed the shortest roots with the smallest root systems, which possibly affected negatively the beginning of flowering and plant height, however, in another study, late flowering $T$. patula cultivars ('Flame', 'Yellow') usually became higher (Neri et al., 2012). The times of appearance of the first flowers and DAS (Day After Sowing) values were summarized in Table 1.

Flower number examined monthly, from early August to early November. In the first measurement, groups of 'Robuszta Kénsárga' cultivated on peat and $50-50 \%$ peat + sand showed the most flowers, but from the second monitoring (and regardless of the medium) the highest growing 'Tiger' stocks gave the largest number (70.8), specifically on peat. This tendency remained until the end of the plant life cycle in November (the number of flowers increased steadily in all groups). Comparing the cultivars, 'Vénusz' developed the fewest flowers, not even averaging 25 pieces when using peat. Plants produced the fewest flowers on sand, in all studies and for all three varieties (Fig. 8). Statistical evaluation of the obtained data revealed that the difference between cultivars could be considered significant even in the case of the same substrate, although the number of flowers of the same cultivar in different media did not differ significantly. The number of flowers increased especially in October and November, but their diameter decreased mainly the latter month.

Examining other T. patula cultivars (in study of Neri et al., 2012), there was positive coherence between flower numbers and the beginning of flowering, thus, earlier blooming cultivars ('Orange', 'Spry') developed more flowers and later varieties ('Flame', 'Yellow') had fewer. In the present instance, although 'Vénusz' flowered at the latest and produced the least numbers of flowers, but then again, the earliest 'Robuszta Kénsárga' had middle values.

\subsection{Flower diameter}

At the first flower-measurement (in August), the largest diameter was obtained in the 'Tiger' group grown on peat $(3.85 \mathrm{~cm})$ and the smallest in the case of 'Vénusz' stocks on sand or peat $(2.75 \mathrm{~cm})$. By the way, the latter cultivar gave the lowest values (usually less than $3.3 \mathrm{~cm}$ ) in every time and media. At the second occasion (in September), 'Tiger' developed the largest sized flowers $(4.36 \mathrm{~cm}$, on sand) and the next month (on the same substrate) 'Robuszta Kénsárga' produced the biggest ones $(4.2 \mathrm{~cm})$.

Table 1. Appearance of the first opened Tagetes patula flowers and DAS values

\begin{tabular}{|c|c|c|c|c|c|c|c|c|c|}
\hline $\begin{array}{c}\text { Cultivar } \\
\text { name }\end{array}$ & \multicolumn{2}{|c|}{ 'Robuszta Kénsárga' } & \multicolumn{3}{c|}{ 'Vénusz' } & \multicolumn{3}{c|}{ 'Tigris' } \\
\hline Substrate & Sand & $\begin{array}{c}\text { Peat }+ \\
\text { sand }(1: 1)\end{array}$ & Peat & Sand & $\begin{array}{c}\text { Peat }+ \\
\text { sand }(1: 1)\end{array}$ & Peat & Sand & $\begin{array}{c}\text { Peat }+ \\
\text { sand }(1: 1)\end{array}$ & Peat \\
\hline $\begin{array}{c}\text { Date of } \\
\text { st flower }\end{array}$ & $\begin{array}{c}20^{\text {th }} \\
\text { July }\end{array}$ & $15^{\text {th }}$ July & $\begin{array}{c}2^{\text {nd }} \\
\text { July }\end{array}$ & $\begin{array}{c}20^{\text {th }} \\
\text { July }\end{array}$ & $20^{\text {th }}$ July & $\begin{array}{c}10^{\text {th }} \\
\text { July }\end{array}$ & $\begin{array}{c}15^{\text {th }} \\
\text { July }\end{array}$ & $15^{\text {th }}$ July & $10^{\text {th }}$ \\
\hline DAS & 69 & 64 & 51 & 69 & 69 & 59 & 64 & 64 & 59 \\
\hline $\begin{array}{c}\text { DAS } \\
\text { (average) }\end{array}$ & \multicolumn{3}{|c|}{61} & \multicolumn{3}{|c|}{65} & & 62 \\
\hline
\end{tabular}




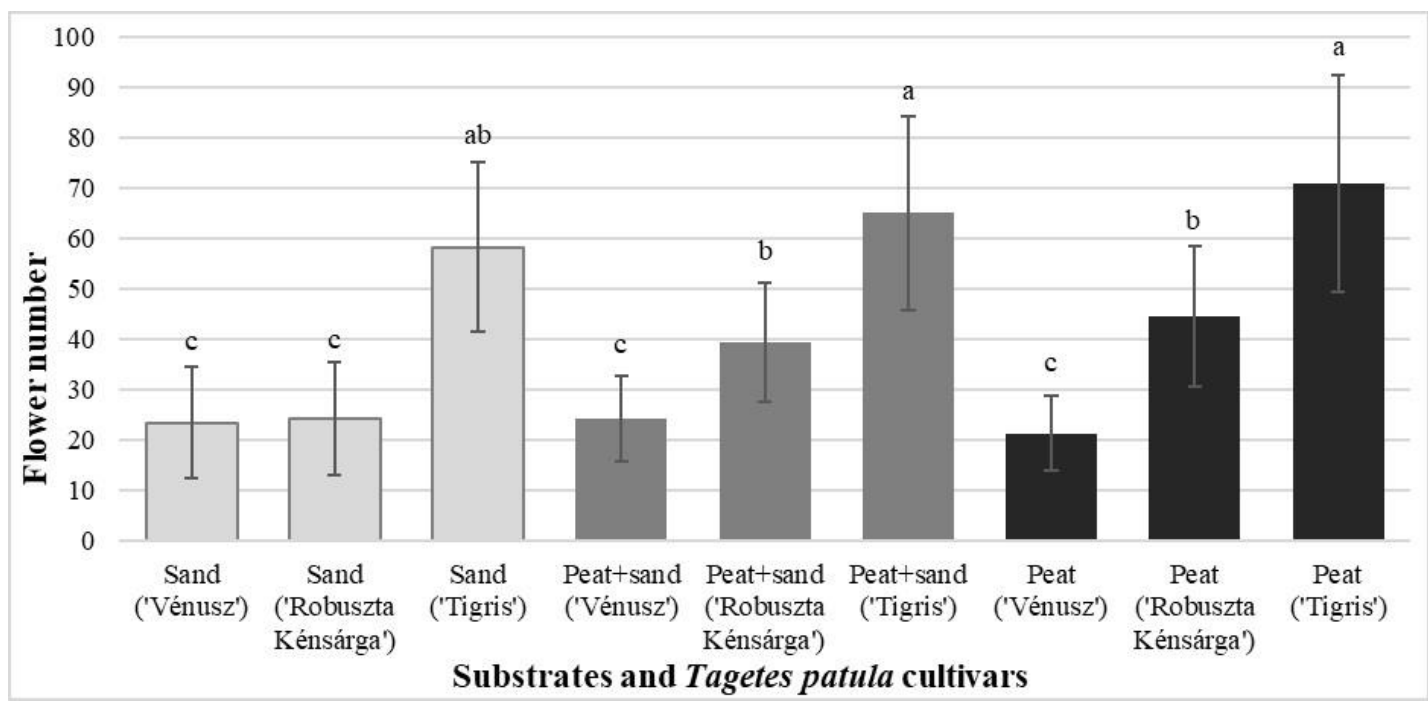

Fig. 8. Flower number of Tagetes patula cultivars on different substrates (November 2019)

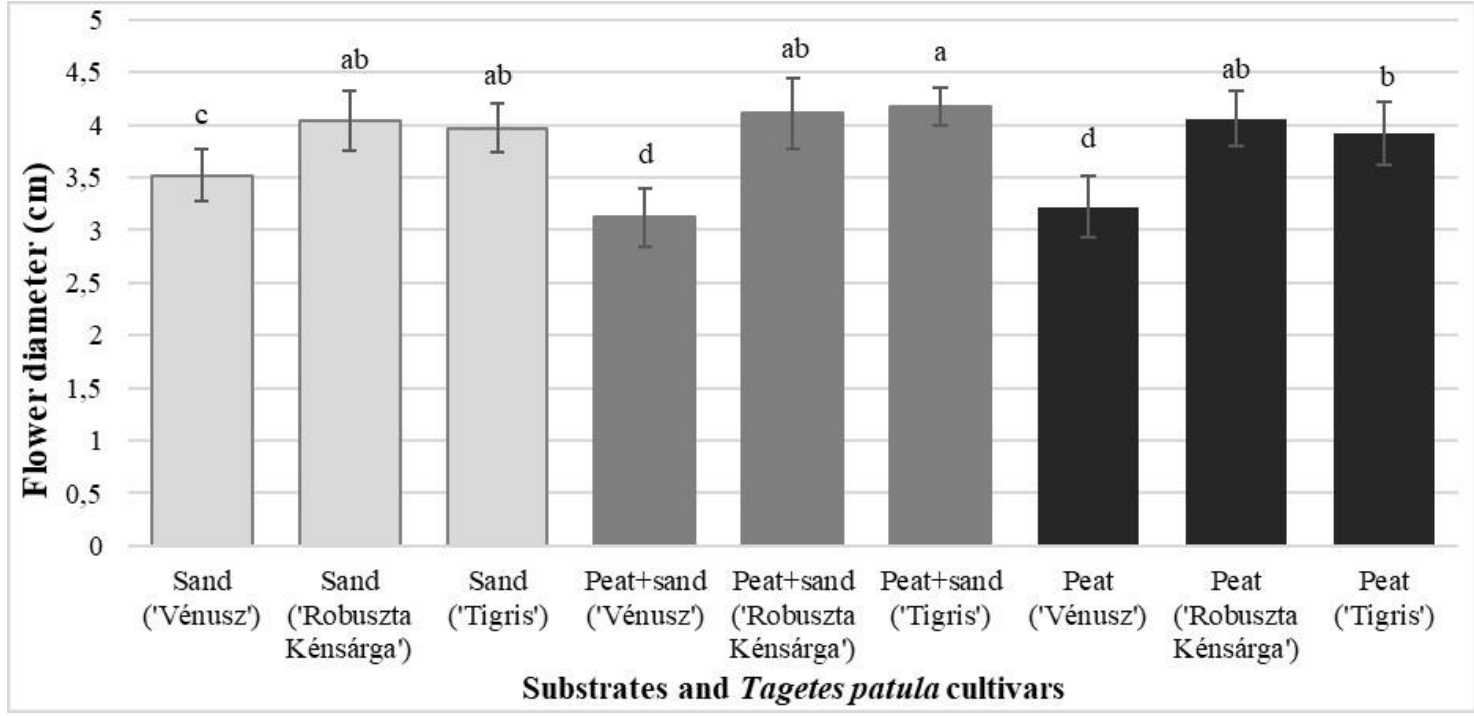

Fig. 9. Flower diameter of Tagetes patula cultivars on different substrates (November 2019)

In the last measurement (in November), 'Tiger' was again in first place, however, the maximum size was only $4.17 \mathrm{~cm}$ (on peat + sand medium. So in general, 'Tiger' developed flowers with the largest (and 'Vénusz' with the smallest) diameter (Fig. 9). The flower size of 'Robuszta Kénsárga' decreased from October to November, while in case of 'Vénusz', increased in all groups over the same period. Statistical evaluation of the flower data have shown that the latter cultivar developed significantly smaller flowers compared to the other two varieties in the same media.

\section{Conclusions}

The use of pure sand resulted the lowest survival values (in case of all cultivars), only half of the plants (20 specimens of 40) remained in the stock planted into this media. The rate of decrease in the number of individuals (if all three cultivars are included) was the smallest in the plants grown in the peat + sand mixture, not more than 7 or 9 individuals. Therefore, combination of these substrates proved to be more favorable, and sand was the least suitable. 
Groups sown in the sand had the longest (and the least expanded) and the shortest (at once the densest) roots in the peat. There were also (and significant) differences between substrates and cultivars; 'Venus' produced the weakest (shortest, sparsely branched) and 'Tiger' had the strongest (longest and thickest) roots. Overall, the length of the roots and their density inversely related to each other.

Plants that developed on sand (regardless of cultivar) became shorter than which grown on peat + sand or even more peat (the latter resulted the tallest specimens). The effect of cultivar was also important: 'Tiger' was the highest and 'Venus' the lowest variety, in all substrates. The first flower opened in the 'Robuszta Kénsárga' stock grown on peat, and the other two varieties also started to bloom earlier on the same substrate. There were also significant differences between cultivars when using the same medium, 'Vénusz' developed the least and 'Tiger' the most flowers. On the other hand, the substrate type also influenced the number of flowers, thus, pure sand resulted the fewest ones, at each cultivars. Flower diameter was the smallest in the case of 'Vénusz' (in all media cases), and 'Tiger' developed the largest flowers. However, as far as the substrate is concerned, it was not evident in the flower diameters of everyone. The role of a given plant variety can generally be considered more important than the type of medium, but if we have choice, peat, even more cheaper mixture of peat + sand is more suitable, as the weakest root systems, lowest plants, least flowers have developed as a result of sand, regardless of variety.

\section{Conflict of interest}

The author declare that the research was conducted in the absence of any commercial or financial relationships that could be construed as a potential conflict of interest.

\section{References}

1. Adams D W (2004) Restoring American Gardens: An Encyclopedia of Heirloom Ornamental Plants, 1640-1940. Portland: Timber Press.

2. Cicevan R, Hassan MA, Sestras AF, Prohens J, Vicente O, Sestras RE, Boscaiu M (2016) Screening for drought tolerance in cultivars of the ornamental genus Tagetes (Asteraceae). PeerJ 4:e2133; DOI:10.7717/peerj.2133

3. Dixit P, Tripathi S, Verma NK (2013) A brief study on marigold. Int Res J Pharm 4:43-48.

4. Dobrowolska A, Janicka A (2014) Changes in the chemical composition of organic media used in cultivation of garden horned violet (Viola cornuta L.) from the Patiola F1 group. J Elem 19(4):959-976.

5. Gutiérrez PRM, Luna HH, Garrido SH (2006) Antioxidant activity of Tagetes erecta essential oil. J. Chile Chem Soc 51(2):883-886.

6. Ferreira AG, Cassol B, Galli S, Da Silveira TS, Stival AL, Andreoli SA (2001) Germinação de sementes de Asteraceae nativas no Rio Grande do Sul, Brasil. Acta Bot Bras 15:231-242.

7. Herrera-Moreno AM, Carranza CE, Chacón-Sánchez MI (2013) Establishment of propagation methods for growing promising aromatic plant species of the Lippia (Verbenaceae) and Tagetes (Asteraceae) genera in Colombia. Agronomía Colombiana 31(1):27-37.

8. Howe TK, Walters WE (1990): Evaluation of Marigold cultivars as bedding plants, spring and fall 1989. Proceedings of the Florida State Horticultural Society 103: 332-337.

9. Kadam PV, Bhingare CI, Sumbe RB, Nikam RY, Patil MJ (2013) Pharmacocognostic, physicochemical and 
phytochemical investigation of Tagetes erecta Linn flowers (Asteraceae). J Biol Sci Opin 1(1):21-24.

10. Kiranmai M, Kazim SM, Ibrahim M (2011) Combined wound healing activity of Gymnema sylvestre and Tagetes erecta Linn. Int J Pharmaceut Appl 2(2):135-140.

11. Maity N, Nema NK, Abedy MK, Sarkar BK, Mukherjee PK (2011) Exploring Tagetes erecta Linn flower for the elastase, hyaluronidase and MMP-1 inhibitory activity. Journal of Ethnopharmacology 137(3): 1300-1305.

12. Manisha RL, Shaik R, Satyanarayana B (2013) Evaluation of anxiolytic activity of flowers of Tagetes erecta Linn (Asteraceae) in rats. J Appl Pharmaceut Sci 39(12):75.

13. Maślanka M., Magdziarz R (2017) The influence of substrate type and chlormequat on the growth and flowering of marigold (Tagetes L.). Folia Horticulturae 29(2):189198.

14. Marcia M., Marques M, Selene M (2011) Larvicidal activity of Tagetes erecta against Aedes aegypti. J Am Mosq Contr Assoc 27(2):156-158.

15. Nikkon FM, Habib MR, Saud ZA (2011) Tagetes erecta Linn and its mosquitocidal potency against Culex quinquefasciatus. Asian Pac J Trop Biomed 1(3):186-188.

16. Neri FCS, Jr. Usberti JA, Usberti R, Paiva PDDO (2012) Morpho-agronomic trait comparisons among Tagetes patula $\mathrm{L}$. cultivars. Ornamental Horticulture 18(1):85-90.

17. Riaz A, Younis A, Taj AR, Karim A, Tario U, Munir S, Riaz S 2013 Effect of drought stress on growth and flowering of marigold
(Tagetes erecta L.). Pak J Bot 45(S1):123131.

18. Raghuveer R, Sreeja K, Sindhuri T, Kumar SA (2011) Antihyperlipidemic effect of Tagetes erecta in cholesterol fed hyperlipidemic rats. Der Pharmacia Lettre 3(5):266-270.

19. Schmidt G (2002) Növényházi disznövények termesztése. Mezőgazda Kiadó, Budapest

20. Schmidt G, Tóth I (1996) Díszfaiskola. Mezőgazda Kiadó, Budapest

21. Singh V, Singh B, Kaul VK (2003) Domestication of wild marigold (Tagetes minuta L.) as a potential economic crop in western Himalaya and north Indian plains. Econ Bot 57(4):535-544.

22. Szabó M (2020) Magyar nemesítésü egynyári virágfajták. Katiötletek Nyomdai Ötletgyár, Szeged

23. Tillyné Mándy A, Honfi P (2011) Növényházi dísznövénytermesztés. Budapesti Corvinus Egyetem, Kertészettudományi Kar, Dísznövénytermesztési és Dendrológiai Tanszék, Budapest

24. Udvardy L (2008) A kertészeti növénytan növényismereti kompendiuma. Budapesti Corvinus Egyetem, Kertészettudományi Kar, Budapest

25. Vargha A (2002) Független minták egyszempontos összehasonlítása új rangsorolásos eljárások segítségével. Statisztikai Szemle 80(4):328-353

26. Vargha A (2008) Új statisztikai módszerekkel új lehetôségek: a ROPstat a pszichológiai kutatások szolgálatában. Pszichológia 28(1):79-100. 